\title{
Aphasia: A Societal and Clinical Appraisal of Pragmatic and Linguistic Behaviours
}

\author{
Glenn M. Goldblum, MA (Sp. \& H.Sc.) (UC, Santa Barbara) \\ Department of Speech Pathology \& Audiology, \\ University of the Witwatersrand, Johannesburg
}

\begin{abstract}
Pragmatic abilities of eleven aphasics classified into fluent and nonfluent groups were examined, and compared with global ratings of communicative adequacy. Further, subjects' pragmatic performance was compared with performance on two standardised linguistic measures. All subjects demonstrated high levels of appropriate pragmatic behaviours and were apparently resourceful in using the context, frequently facilitated by use of compensatory communicative strategies. Similar and different pragmatic deficits were noted for both groups. Regardless of classification and linguistic severity, subjects were less impaired on pragmatic compared to standardised linguistic measures. Implications were highlighted, emphasising the importance of pragmatics relative to other aspects of language function.
\end{abstract}

\section{OPSOMMING}

Die pragmatiese vermoëns van elf afasie-pasiënte, wat ingedeel is in 'n vlot - en 'n onvlotgroep, is ondersoek en hul kommunikatiewe vaardighede is onderling vergelyk. Die proefpersone se pragmatiese prestasie is ook vergelyk met hul prestasie op twee gestandaardiseerde linguistiese toetse. Al die proefpersone het bewys gelewer van hoë vlakke van toepaslike pragmatiese gedrag en was oënskynlik vindingryk om die konteks te gebruik vir kompensatoriese kommunikatiewe strategieë. Tekortkominge in die twee groepe was soms dieselfde en soms verskillend van aard. Ongeag die klassifikasie van die groepe en die graad van linguistiese onvermoë, was die proefpersone deurgaans pragmaties minder belemmer as op die linguistiese vlak. Gevolgtrekkings is beklemtoon, wat die relatiewe belang van die pragmatiek tot ander aspekte van taalfunksionering onderstreep.

As speech-language pathologists, one of our primary concerns has always been to improve communicative effectiveness of the individuals we serve. In attempting to meet this goal, the intervention strategies we have used have been continually refined and revised-molded by the changing theoretical views of language over the past several decades. Earlier in our history many investigators including Johnson (1946) and Van Riper (1939 cited by Prutting, 1982a) stressed the need for our goals to be mutually acceptable to both the client and society. Much of this societal perspective was lost over the past few decades, perhaps in the name of objectivity and accountability.

More recently, researchers in applied behavioural research and in the field of child and adult language disorders, (e.g. Kazdin (1977); Mueller (1983); Prutting (1982a); Prutting and Kirchner (1983); and Prutting, Kirchner, Hassan and Buen (1984)) have pointed out the need to move back clinically to viewing communication disorders from a social perspective, taking context into account, rather than attempting to control it. Despite this proposed change in perspective, clinical aphasiologists still need to concern themselves with identifying behaviours and effecting changes that make socially relevant differences in the client's life.

As in the discipline of science, the field of acquired adult aphasia has undergone many paradigmatic shifts which have resulted in conceptual and methodological reorganisation. At present there is a contemporary and ongoing shift towards a functionalist paradigm which appears to provide promise of a different theoretical framework for examining and attempting to understand the aphasic communication problem. Holland's observation (1977) that "aphasics probably communicate better than they talk" (p.173), which views aphasia as a communication (rather than a language) problem, reflects this broadened functional perspective.
A perusal of the more recent literature reveals that despite the growing interest towards pragmatics in aphasia, a diverse and large list of behaviours are included under the general rubric of pragmatics, in the absence of a comprehensive theoretical framework of natural aphasic communication. Such a framework remains to be developed to help clinicians incorporate pragmatics more effectively into the treatment process.

While most traditional and current assessments of aphasic language focus on the structural aspects of their verbal output, a few researchers have begun to be challenged by, and address the assessment of diverse communicative functions in aphasia. Using a variety of communication assessment protocols and observational measures a few investigators including Guilford and O'Connor (1982); Holland (1980, 1982); and Penn (1983) have demonstrated generally superior pragmatic abilities with little correlation between traditional syntactic profiles and communicative performance. While their data has furthermore resulted in support for Holland's belief $(1982,1983)$ in the preservation of communicative competence in aphasia, Penn (1983) has warned that since the social context of communication is so redundant, we may be overestimating the aphasic's ability. Communicative competence compared to linguistic competence may thus best be viewed as less impaired in aphasia rather than intact.

The most comprehensively linguistic study evident in this regard appears to be that by Penn (1983), who developed a Profile of Communicative Appropriateness (PCA) based upon a relatively comprehensive taxonomy derived from child language literature. Penn used her PCA (Penn, 1983) and the Language Assessment Remediation and Screening Procedure (LARSP) (Crystal, Garman and Fletcher, 1976 cited by Penn, 1983) to obtain and compare com- 
municative and linguistic profiles of fourteen predominantly left hemisphere aphasic subjects across a range of aphasic types as deby the Boston Diagnostic Aphasia Examination (BDAE) (Goodglass and Kaplan, 1972 cited by Penn, 1983). The results (Goodglass and Kaplan, cited by Penn, 1983) of the LARSP syntactic anasia type, and to a lesser extent severicorrelated closely with aphatyses demonstrated essentially idiosynty. In contrast, pragmatic anumication skills by individual subjects, cratic retention of cessarily related to subjects' capacities on a synwhich were not necessand type distinctions did not always account for subject clusters on the PCA (Penn, 1983), particularly when individual scales were considered, although severity was postulated to relate more closely to appropriate communicative performance than site of lesion or type of aphasia as predicted by traditional tests of aphasia.

Though exploratory in nature, Penn's data (1983) suggesting the relative independence of syntactic and pragmatic aspects of aphasia are extremely provocative, raising concern with two important issues. Firstly they cast some doubt on the validity of traditional classification schemes and their ability to reflect functional communicative competence. Alternatively, Penn's data highlights the need to consider structural and functional data together to facilitate a more comprehensive evaluation of an aphasic's communicative competence.

In contrast to these data, in the area of child language disorders, Prutting et al, (1984) have recently demonstrated clearly different pragmatic profiles across normal, language and articulation disordered groups of children using a societally-based Pragmatic Protocol (Prutting 1982b) inclusive of the behaviours discussed in the literature. Their documentation of a relationship between pragmatic function and linguistic performance, (which contrasts with the limited data reported in the adult aphasic literature) may reflect Prutting et al's (1984) use of societal criteria to evaluate the childrens' language use, using a protocol based upon a sound theoretical frame- work (Austin, 1962; Searle, 1969 cited by Prutting et al, 1984) to evaluate a range of pragmatic behaviours. Furthermore, Mueller's data (1983) revealing a strong relationship between this protocol and measures of societal judgements, highlighted the apparent value of this tool as a means of approaching the assessment of social competence.

While Prutting and Kirchner (1983), have emphasised the necessity to gather and analyse data utilising methods which reflect advances in our theoretical knowledge, to date there appears to be no study in the field of aphasia utilising societal criteria to analyse the individual's pragmatic strengths and deficits across a range of pragmatic behaviours. As of yet we have no clear understanding of how pragmatic abilities and deficits stratify across different types of aphasic clients.

Furthermore, despite the increasing number of studies examining discrete pragmatic behaviours in aphasic adults, a marked paucity is nevertheless apparent of investigations evaluating pragmatic function in relationship to linguistic performance. The theoretical, clinical and research consequences of using a societal Pragmatic Protocol (Prutting, 1982b) in conjunction with traditional clinical measures are apparently far-reaching. Not only would the effects of communicative behaviour in relation to societal values be considered, but attempts would be made to merge clinical and societal goals into our intervention programmes, enhancing the overall communicative competence of the aphasic individual. In view of these issues, this study examined the pragmatic abilities of eleven aphasic adults classified into fluent and non-fluent groups using the Western Aphasia Battery (WAB) (Kertesz, 1980) taxonomy, and compared them with global ratings of communicative adequacy. Furthermore, subjects' performance on a societal Pragmatic Protocol (Prutting, 1982b) was compared with performance on two clinical linguistic measures - the WAB (Kertesz, 1980) and the Communicative Abilities in Daily Living (CADL) (Holland, 1980).

Table 1 Descriptive data for subjects used in the Study

\begin{tabular}{|c|c|c|c|c|c|c|c|c|c|c|c|}
\hline Subject & Sex & Age & $\begin{array}{c}\text { Months } \\
\text { post } \\
\text { onset }\end{array}$ & $\begin{array}{l}\text { Educational } \\
\text { Level }\end{array}$ & $\begin{array}{l}\text { Premorbid } \\
\text { Occupation }\end{array}$ & $\begin{array}{c}\text { Premorbid } \\
\text { Communicative- } \\
\text { ness rating on } \\
\text { scale from } \\
1-7^{*}\end{array}$ & $\begin{array}{c}\text { Apraxia } \\
\text { rating } \\
\text { on scale } \\
\text { from } \\
0-7 * *\end{array}$ & $\begin{array}{c}\text { Dysarthria } \\
\text { rating } \\
\text { on scale } \\
\text { from } \\
0-7^{* *}\end{array}$ & $\begin{array}{c}\text { Classification } \\
\text { of type of } \\
\text { aphasia on } \\
\text { Western Aphasia } \\
\text { Battery }\end{array}$ & $\begin{array}{l}\text { Behavioural } \\
\text { Classification }\end{array}$ & $\begin{array}{c}\text { Severity } \\
\text { rating on } \\
\text { Western } \\
\text { Alphasia } \\
\text { Battery }\end{array}$ \\
\hline 1 & $\mathbf{M}$ & 70 & 7 & High school & $\begin{array}{l}\text { Retired auto } \\
\text { service manager }\end{array}$ & 3 & 0 & 0 & Wernicke's & Fluent & Moderate \\
\hline 2 & $\mathrm{M}$ & 58 & 27 & College & $\begin{array}{l}\text { Retired Navy test } \\
\text { pilot }\end{array}$ & 3 & 2 & 0 & Conduction & Fluent & $\begin{array}{l}\text { Mild- } \\
\text { moderate }\end{array}$ \\
\hline 3 & F & 51 & 8 & loth Grade & $\begin{array}{l}\text { Laundromat } \\
\text { assistant, } \\
\text { bartender }\end{array}$ & 4 & 0 & 0 & Conduction & Fluent & Mild \\
\hline 4 & $\mathrm{M}$ & 69 & 5 & 8th grade & $\begin{array}{l}\text { Retired security } \\
\text { guard }\end{array}$ & 5 & 0 & 2 & Anomic & Fluent & Mild \\
\hline 5 & $\mathrm{~F}$ & 51 & 7 & High School & $\begin{array}{l}\text { Retired legal } \\
\text { secretary }\end{array}$ & 3 & 0 & 0 & Anomic & Fluent & Mild \\
\hline 6 & $\mathrm{~F}$ & 69 & 3 & MA (art) & $\begin{array}{l}\text { Retired general } \\
\text { manager }\end{array}$ & 1 & 0 & 0 & Anomic & Fluent & Mild \\
\hline 7 & $M$ & 67 & 9 & $\begin{array}{l}\text { lncompleted } \\
\text { MA }\end{array}$ & $\begin{array}{l}\text { Retired military } \\
\text { colonel }\end{array}$ & 4 & 5 & 0 & Broca's & Non-fluent & Moderate \\
\hline . 8 & $M$ & 68 & 300 & 8th grade & $\begin{array}{l}\text { Retired carpet \& } \\
\text { tile salesman }\end{array}$ & 2 & 2 & 0 & Broca's & Non-fluent & Mild \\
\hline 9 & $\mathbf{M}$ & 65 & 40 & High School & Retired plumber & 2 & 3 & 0 & Broca's & Non-fluent & Mild \\
\hline 10 & $\mathrm{M}$ & 54 & 16 & College & $\begin{array}{l}\text { Retired licensed } \\
\text { Land Surveyor }\end{array}$ & 2 & 3 & 0 & Broca's & Non-fluent & Mild \\
\hline 11 & $\mathrm{~F}$ & 60 & 120 & High School & Retired meter maid & 2 & 0 & 0 & Broca's : & Non-fluent & Mild \\
\hline
\end{tabular}

*Key: 1 = superior communicativeness $7=$ uncommunicative 


\section{METHOD}

SUBJECTS

Eleven English speaking aphasic adults were selected for this study according to certain criteria. These included confirmed presence of aphasia due to a completed, single, left hemisphere Cerebrovascular accident, neurological stability and the absence of gross concomitant problems. All aphasics were required to have absent to moderate symptoms of apraxia and/or dysarthria ranging from $0-5$ on a severity scale of 7 (Wertz, 1984). Portions of the Motor Speech Evaluation (Wertz, Weiss, Kurtzke et al., 1978) and the spontaneous section of the WAB (Kertesz, 1980) were used to determine this.

A representation of both fluent and non-fluent aphasics was required as determined by the classification on the fluency subtest of the WAB (Kertesz, 1980). Since fluency appears to be one of the most important factors differentiating the aphasia types, and is a dimension that has been emphasised in more recent behavioural classifications of aphasia, the fluent : non-fluent dichotomy was selected in this study to facilitate comparison of pragmatic abilities in fluent : non-fluent aphasic subjects. Global aphasics werc excluded to control for severity of the sample examined (Wertz, 1984). Table 1 illustrates relevant case history information pertaining to the aphasics.

Pragmatic Protocol (Prutting, 1982b) is a societal protocol which reflects the theoretical shift to place language within the context of socialisation (Prutting, 1982a). In contrast to traditional measures, the Pragmatic Protocol (Prutting, 1982b) examines the individual's pragmatic strengths and deficits within the conversational discourse, and across a variety of contexts. "The resulting configuration allows the clinician to evaluate pragmatic function in relation to linguistic performance" (Prutting, et al., 1984, p.24). The Pragmatic Protocol (Prutting, 1982b) has been developed over a four year period and pilot tested at the University of California, Santa Barbara Specch and Hearing Centre (Prutting, et al., 1984). It comprises a pool of 32 behaviours all known to be developed and used appropriately by children entering school, adolescents and adults. This tool was designed to be usced while observing individuals engaged in spontaneous conversation during unstructured communicative interactions (Prutting, et al., 1984). The Pragmatic Protocol (Prutting, 1982b) was developed using the following criteria: theoretical framework, representative range of behaviours found in normal development, and inter-investigator reliability (Prutting, et al., 1984).

Theoretical Framework: The Speech Act Theory proposed by Austin (1962) and Searle (1969) (cited by Prutting et al., 1984), constitutes the framework underlying this Pragmatic Protocol (Prutting, 1982b).

The 32 behaviours werc organised within the following speech act categories. The utterance act includes 13 behaviours which form the verbal, non-verbal and paralinguistic aspects of production, characterising the "raw material" of the communicative act (Prutting and Kirchner, 1983). The propositional act is comprised of 4 behaviours which define the linguistic dimensions of meaning. The 15 items comprising the illocutionary and perlocutionary acts constitute the reciprocal behaviours that regulate discourse between speakers. The illocutionary act represents the speaker's intention, while the perlocutionary act represents the speaker or listeners' effects.

\section{Modification to the Pragmatic Protocol}

In addition, the investigator added two behaviours - namely personal appearance and affect (under the utterance act), since per-

Die Suid-Afrikaanse Tydskrif vir Kommunikasieafwykings, Vol. 32, 1985 sonal clinical experience and the literature (e.g. Holland, 1980; 1983; Penn, 1983) seemed to highlight their importance in aphasia.

\section{Scoring}

Since the Pragmatic Protocol (Prutting, 1982b) is a societal appraisal rather than a clinical appraisal, the judgement made is not whether the behaviour is correct or incorrect in a clinical sense, but rather if the behaviour is penalising or not. The investigator must decide whether society will penalise an individual for exhibiting a particular behaviour. Thus, a behaviour may be incorrect but not necessarily judged as inappropriate (Prutting, et al, 1984). The following guidelines were used to judge each of the behaviours listed on the Pragmatic Protocol (Prutting, 1982b):

- Appropriate: Behaviours are marked appropriate if they facilitate the communicative interaction, or are neutral.

- Inappropriate: Bchaviours are judged inappropriate if they detract from the communicative exchange and penalise the individual.

- No opportunity to observe: When the evaluator has insufficient information to judge the behaviour as appropriate or inappropriate (Prutting and Kirchner, 1983).

\section{Scale of Overall Communicative Adequacy}

A 5 point subjective rating scale (derived from Holland's protocol for adult aphasia (1982)) was used to obtain an estimate of the aphasics' and their partners' overall communicative adequacy. Each rating would be converted into a percentage out of a total of 5 for comparison purposes.

\section{Testing Procedure and Schedule}

Preselection tests and standardised procedures were administered over two sessions. Aphasic clients were seen individually in various facilities, or in their home environments. A constant task presentation order was maintained. Firstly, portions of the Motor Speech Evaluation (Wertz, et al., 1978) and the oral portion of the WAB (Kertesz, 1980) were administered. During the second session the CADL (Holland, 1980) was administered, and each aphasic was videotaped while conversing with a familiar comfortable partner of his/her choice with whom they had some shared history.

Whilc conversational partner and topic were not specified, the affiliative nature of the relationship, and topic familiarity were held constant across all aphasics to facilitate and maximise conversational flow.

\section{RESULTS}

\section{PRAGMATIC PROTOCOL DATA}

While fluent aphasics demonstrated significantly superior pragmatic skills compared with non-fluent aphasics (see Table 2), all individuals demonstrated a high level of appropriate pragmatic behaviours which manifested as retained social competence (see Figure 1).

Table 2 Between group comparison of percent appropriate pragmatic behaviours on Pragmatic Protocol in fluent and non-fluent groups

\begin{tabular}{|c|c|c|c|}
\hline \multicolumn{2}{|c|}{ Fluent Group $(\mathrm{N}=6)$} & \multicolumn{2}{|c|}{ Non-fluent Group ( $N=5$ ) } \\
\hline $\begin{array}{l}\overline{\mathrm{x}} \\
\text { Range } \\
\text { s.d. }\end{array}$ & $\begin{array}{l}86.27 \% * \\
79.41-94.11 \% \\
2.07\end{array}$ & $\begin{array}{l}\bar{X} \\
\text { Range } \\
\text { s.d. }\end{array}$ & $\begin{array}{l}75.88 \% \\
61.76-85.29 \% \\
2.95\end{array}$ \\
\hline
\end{tabular}

$*_{t-\text { test }}$ significance at $\mathrm{p}<0.05$ 


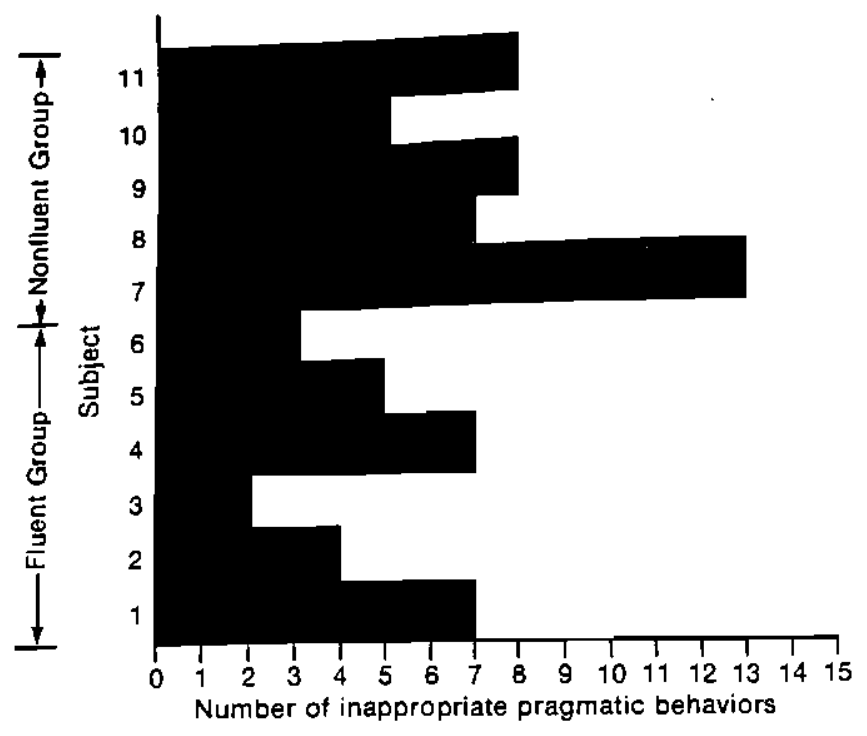

Figure 1 Number of Inappropriate Pragmatic Behaviours on Pragmatic Protocol for Individual Subjects Within Each Group

Table 3 Percentage of inappropriate pragmatic behaviours for fluent and non-fluent aphasics in each speech act category

\begin{tabular}{|c|c|c|c|}
\hline Group & $\begin{array}{c}\text { Utterance } \\
\text { Act }\end{array}$ & $\begin{array}{c}\text { Propositional } \\
\text { Act }\end{array}$ & $\begin{array}{c}\text { Illocutionary } \\
\text { Perlocutionary } \\
\text { Act }\end{array}$ \\
\hline Fluent & $11.1 \%$ & $33.3 \%$ & $11.1 \%$ \\
\hline Non-fluent & $10.6 \%$ & $55 \%$ & $29.3 \%$ \\
\hline
\end{tabular}

Aphasics. were apparently resourceful in using the context, frequently facilitated via the use of compensatory communicative strategies. These included word finding strategies, appropriate repair and revision strategies, and a range of largely effective idiosyncratic strategies such as non-talking, to avoid communicative failure. The highest proportion of inappropriate pragmatic behaviour displayed by both groups was in the propositional act category. The non-fluent group demonstrated significantly greater difficulty on the perlocutionary/illocutionary act level, reflecting greater problems in managing the dyad (see Table 3 and Figure 2).

Examination of profiles of pragmatic deficits across fluent and nonfluent groups revealed interesting similarities and differences. Firstly, the nearly comparable presence of the following four inappropriate pragmatic behaviours across fluent and non-fluent groups: specificity/accuracy $(100 \%)$ in both groups, fluency $(50 \%)$ and $(60 \%)$; pause time $(50 \%)$ and $(80 \%)$; quantity/conciseness $(60 \%)$ and $(100 \%)$ across fluent and non-fluent groups respectively. It is noteworthy that while fluency was rank ordered third as compared to sixth for fluent and non-fluent groups respectively, more nonfluent aphasics $(60 \%)$ were penalised for this behaviour than fluents $(50 \%)$. Generally, the prevalence of these four deficits across both fluent and non-fluent aphasics would seem to appropriately reflect the inherent problem of aphasia, irrespective of classification.

In contrast to these similarities, two inappropriate pragmatic behaviours were very prominent in the non-fluent group, and either relatively rare or absent in the fluent group. These were word order $(16 \%)$ and $(100 \%)$; variety of speech acts $(0 \%)$ and $(100 \%)$ in the fluent and non-fluent groups respectively. These data clearly seem to differentiate the fluent from the non-fluent aphasics suggesting that rules of dyadic interaction are most difficult for the non-fluent aphasics in this investigation. In view of the presence of similar and different inappropriate pragmatic behaviours within the fluent and non-fluent groups used in this study, it is apparent that the Pragmatic Protocol (Prutting, 1982b) both does and does not differentiate between these aphasic groups.

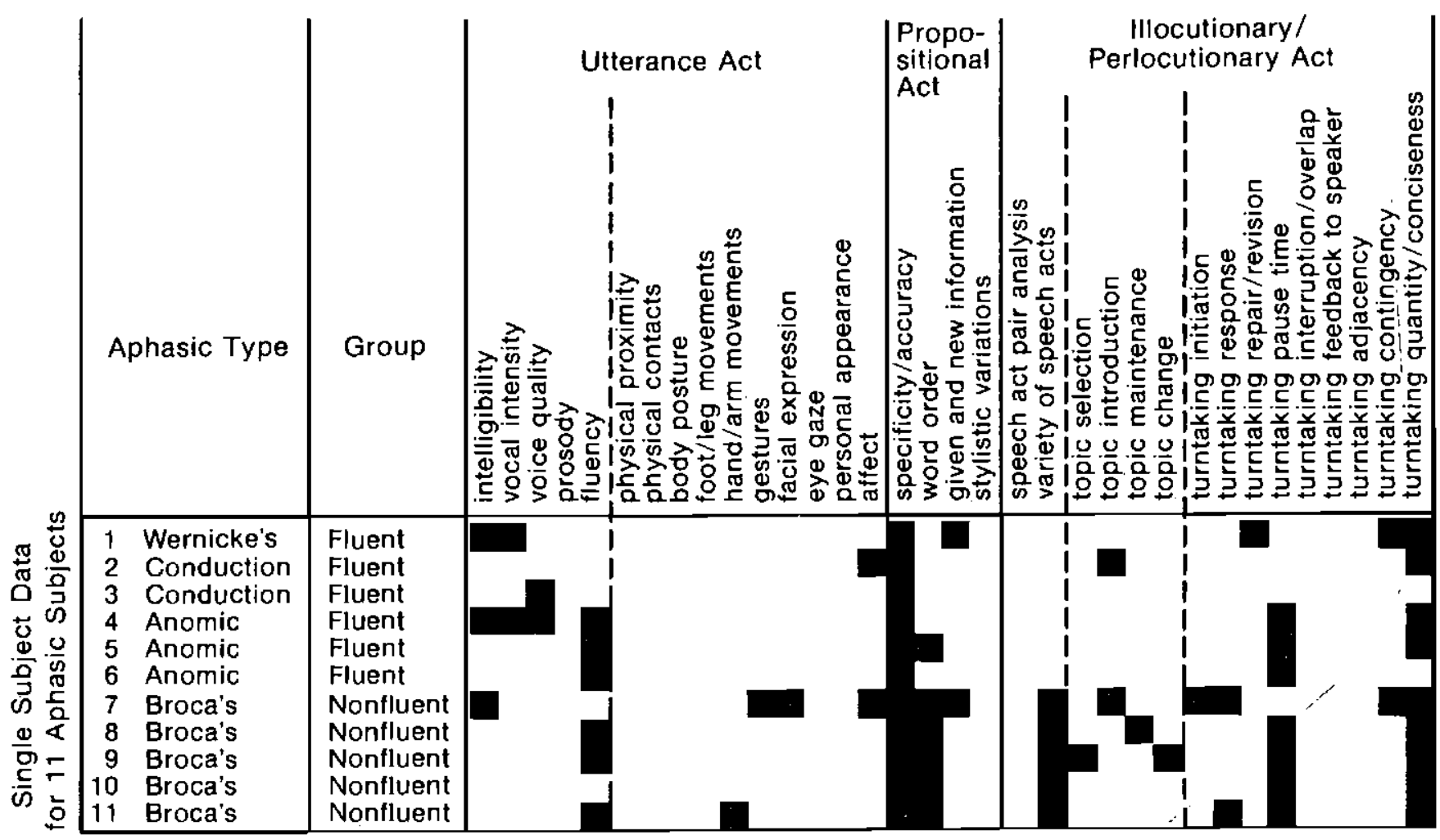

Figure 2 Inappropriate Pragmatic Behaviours Within Each Speech Act Category on Pragmatic Protocol for Individual Subjects in Fluent and Non-fluent Groups 
Aphasia : a Societal and Clinical Appraisal of Pragmatic and Linguistic Behaviours

COMPARISON OF PERFORMANCE ON THE PRAGMATIC PROTOCOL AND THE SCALE OF OVERALL COMMUNICATIVE ADEQUACY

Performance on the Scale of Overall Communicative Adequacy (Holland, 1982) revealed the same trend evidenced in the fluent aphasic groups' overall superior performance on the Pragmatic Protocol (Prutting, 1982b) thereby substantiating the Pragmatic Protocol (Prutting, 1982b) as a measure reflecting communicative competences (see Table 4). Despite the aphasic individuals' use of largely effective compensatory strategies to enhance communicative success, communicative burden on their respective partners was nevertheless high, resulting in their use of a variety of frequently facilitative strategies (e.g. probing, and encouraging the aphasics' use of strategies). These data highlighted the inherently interactive nature of the communicative process.

Table 4 Mean communicative adequacy ratings for fluent and non-fluent groups and their partners on the Scale of Overall Communicative Adequacy

\begin{tabular}{|c|c|}
\hline Fluent Group* & Non-fluent Group* \\
\hline $\begin{array}{l}\bar{X}=3.5(70 \%) \\
\text { Range }=34 \\
\text { s.d. }=0.55\end{array}$ & $\begin{array}{l}\overline{\mathrm{X}}=2.4(48 \%) \\
\text { Range }=1.3 \\
\text { s.d. }=0.89\end{array}$ \\
\hline Partner** & Partner"** \\
\hline $\begin{array}{l}\bar{X}=4.6(92 \%) \\
\text { Range }=4-5 \\
\text { s.d. }=0.52\end{array}$ & $\begin{array}{l}\overline{\mathrm{X}}=4(80 \%) \\
\text { Range }=2.5 \\
\text { s.d. }=1.22\end{array}$ \\
\hline
\end{tabular}

Key: "Rating of $1=$ minimal communicative ability

Rating of 5 = normal communicative ability

**Rating of 1 = nominal skill in communicating with aphasic

Rating of $5=$ competence in communicating with aphasic

CORRELATION BETWEEN PRAGMATIC PROTOCOL SCORES AND PERFORMANCE ON THE WESTERN APHASIA BATTERY AND THE COMMUNICATIVE ABILITIES IN DAILY LIVING IN FLUENT AND NON-FLUENT APHASIC INDIVIDUAL'S

The relationship between societal and clinical profiles was examined and revealed some interesting trends. While significant differences were obtained between social competence scores of fluent and nonfluent aphasics on the Pragmatic Protocol (Prutting, 1982b) $(p<0.05)$, differences between these two groups on the clinical measures (namely the WAB (Kertesz, 1980) and the CADL (Holland, 1980)) were found to be non-significant $(p>0.05)$. (See Table 5)
The relatively small range of mean percentage scores on the Pragmatic Protocol (Prutting, 1982b) for the fluent and non-fluent groups (79.41-94.11\% and 61.76-85.29\% respectively) as compared with the greater ranges of scores for these groups on the WAB (Kertesz, 1980) and the CADL (Holland, 1980) (see Figure 3) was interesting, yielding several implications. This reflected an overall higher group mean of appropriate pragmatic behaviours (social competence scores) across fluent and non-fluent groups irrespective of severity. Further, since the Pragmatic Protocol (Prutting, 1982b) is based on societal rather than clinical criteria (used by the WAB (Kertesz, 1980) and the CADL (Holland, 1980), these overall higher scores may also reflect the discrepancies reported in the literature, i.e. related to societal and clinical ratings of aphasic communicative competence.

Computational correlation coefficients were performed in order to determine and compare the relationship between societal and clinical performance of (a) fluent and non-fluent aphasic individuals

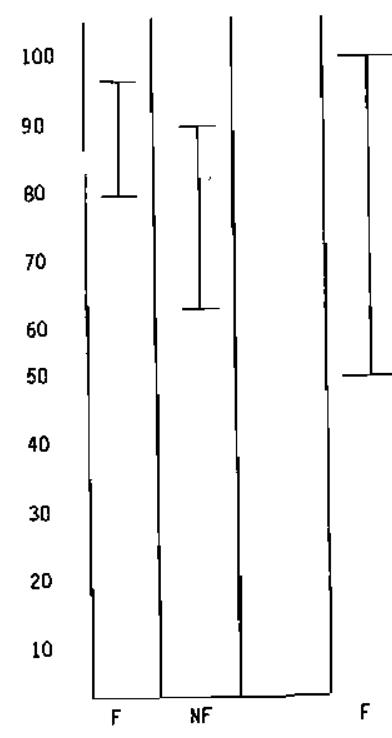

Aphasic group and measure
Pragmatic Protocol

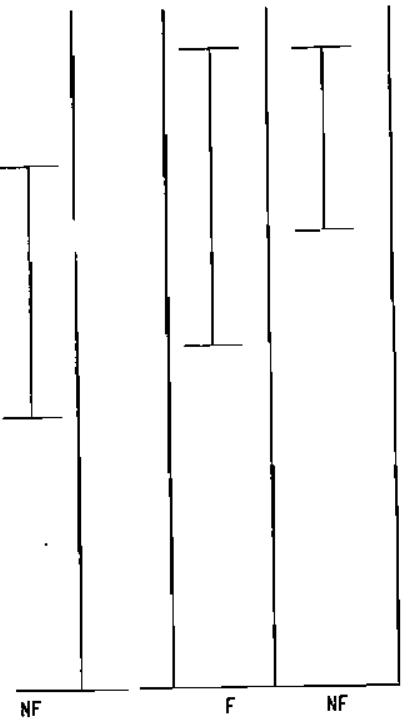

CADL :ey: $\begin{aligned} F & =\text { fluent group } \\ \mathbf{N F} & =\text { non-fluent group }\end{aligned}$

Figure 3 Percentage group means and ranges of appropriate pragmatic behaviour on the Pragmatic Protocol, and correct responses on the Western Aphasia Battery and Communicative Abilities in Daily Living.

Table 5 Percentage group means, ranges and standard deviations on the Pragmatic Protocol, the Western Aphasia Battery and the Communicative Abilities in Daily Living

\begin{tabular}{|c|c|c|c|c|c|c|}
\hline \multirow[b]{2}{*}{ Measure } & \multicolumn{3}{|c|}{ Fluent Group } & \multicolumn{2}{|r|}{ Non-fluent Group } & \multirow[b]{2}{*}{ s.d. } \\
\hline & $\overline{\mathrm{x}}$ & Range & s.d. & $\overline{\mathbf{x}}$ & Range & \\
\hline $\begin{array}{l}\text { Pragmatic } \\
\text { Protocol }\end{array}$ & $86.26 \% *$ & $79.41 \%-94.11 \%$ & 2.07 & $75.88 \% *$ & $61.76-85.29 \%$ & 2.95 \\
\hline WAB & $74.92 \%$ & $46.48 \%-96.26 \%$ & 18.99 & $64.56 \%$ & $42.96 \%-78.57 \%$ & 13.64 \\
\hline CADL & $81.25 \%$ & $52.94 \%-97.79 \%$ & 22.95 & $86.32 \%$ & $72.79 \%-94.85 \%$ & 11.72 \\
\hline
\end{tabular}

*t-test significance at $\mathrm{p}<0.05$ 
separately and (b) combined (see Table 6). The non-significant correlation (for both fluent and non-fluent groups) between the Pragmatic Protocol (Prutting, 1982b) and the WAB (Kertesz, 1980), and the Pragmatic Protocol (Prutting, 1982b) and the CADL (Holland, 1980) suggested that these tests are measuring different aspects of an individual's communicative competence, and would not necessarily predict his/her performance on one or other test.

Table 6 Computational correlation coefficient among three measures of fluent and non-fluent aphasics' communicative abilities

\begin{tabular}{|l|c|c|c|}
\hline Group & $\begin{array}{c}\text { Pragmatic Protocol } \\
\text { + WAB }\end{array}$ & $\begin{array}{c}\text { Pragmatic Protocol } \\
\text { + CADL }\end{array}$ & WAB + CADL \\
\cline { 1 - 2 } $\begin{array}{l}\text { Fluent } \\
\text { Non-fluent }\end{array}$ & 0.20 & 0.34 & $0.97^{*}$ \\
$\begin{array}{l}\text { Non-fluent } \\
\text { minus Subject 7 }\end{array}$ & 0.83 & 0.13 & 0.57 \\
$\begin{array}{l}\text { Fluent + } \\
\text { non-fluent } \\
\text { combined }\end{array}$ & 0.32 & 0.28 & $0.99^{*}$ \\
$\begin{array}{l}\text { Fluent + } \\
\text { non-fluent } \\
\text { combined } \\
\text { minus Subject 7 }\end{array}$ & 0.53 & 0.05 & 0.75 \\
\hline
\end{tabular}

$*_{t \text {-tess significance at } \mathrm{p}<0.05}$

In the fluent group, the CADL (Holland, 1980) correlated significantly with the WAB (Kertesz, 1980) $(\mathrm{S}=0.97)(\mathrm{p}<0.05)$ reflecting the CADL's (Holland, 1980) almost perfect ability to predict a client's communicative abilities in daily living (Holland, 1980). While the non-fluent group revealed a non-significant correlation between the WAB (Kertesz, 1980) and CADL (Holland, 1980) $(S=0.57)(p>0.05)$, removal of Subject seven's extremely variable data reduced the disproportion and resulted in comparable correlational trends between the fluent and non-fluent groups (see Table 6). It is apparent from these data, that the highest correlation exists between the WAB (Kertesz, 1980) and the CADL (Holland, 1980) while performance on the Pragmatic Protocol (Prutting, 1982b) would not necessarily predict performance on the CADL (Holland, 1980) and the WAB (Kertesz, 1980). Similar correlational trends occur when the three measures of communicative abilities are compared for the fluent and non-fluent groups combined, and when the 'outsider' Subject seven is removed (see Table 6). The overall consistent pattern of generally low non-significant correlation of the Pragmatic Protocol (Prutting, 1982b) with the CADL (Holland, 1980), and even more so with the WAB (Kertesz, 1980) $(p>0.05)$ when fluent and non-fluent groups are examined separately, and combined (excluding Subject seven's data) yield some interesting implications - most notably the apparent trustworthiness of the data based on the stability of data. Thus it is evident that fluent and non-fluent aphasics perform consistently superiorily on societal as compared to clinical measures. While these data are based upon a small and heterogeneous sample, which may have tended to inflate the obtained correlation coefficients, their implications are provocative.

\section{- DISCUSSION}

\section{A Pragmatic Perspective of Aphasia}

In accordance with several investigators (e.g., Davis and Wilcox, 1981, Foldi, Cicone and Gardner, 1983; Guilford and O'Connor, 1982; Holland, 1977, 1982, 1983; Penn, 1983; Wilcox, 1983) the results of this study revealed a high level of appropriate pragmatic behaviours manifesting as retained social competence across all aphasic subjects. Generally despite their linguistic impairments, aphasics are apparently resourceful in using the context effectively in conversational interactions, frequently facilitated via the use of compensatory communicative strategies (including for example, simplification, humour, circumlocutions and interjections to maintain turns). These strategies reflecting the aphasics' attempts to readapt communicatively to their cerebral insult were found by Penn (1983) to constitute retained communicative competence.

While the Pragmatic Protocol (Prutting, 1982b) was able to differentiate between the fluent and non-fluent group of aphasics on the basis of the almost exclusive presence of two inappropriate pragmatic behaviours in the non-fluent group, namely, word order and variety of speech acts, in view of the following factors, caution needs to be observed in concluding that this tool clearly differentiates between fluent and non-fluent aphasics: the combined presence of four inappropriate pragmatic behaviours across fluent and nonfluent groups (i.e., specificity/accuracy, fluency, pause time, and quantity/conciseness); as well as the scattered presence of pragmatic deficits across individual aphasics, irrespective of classification. These latter idiosyncratic deficits attest to the perplexing feature of variability that is so characteristic of aphasia (Holland, 1983). Furthermore, the small sample of fluent aphasics manifesting mild linguistic deficits combined with a relative absence of pragmatic deficits may well have inflated the data. Further research using larger samples of equivalent types of aphasic subjects is clearly needed to clarify these issues.

To the present writer's knowledge, Penn's investigation comparing syntactic and pragmatic abilities of aphasics appears to be the one most closely related to the research questions addressed in this study. It is therefore interesting to speculate why Penn's Profile of Communicative Appropriateness (PCA) (Penn, 1983), unlike the Pragmatic Protocol (Prutting, 1982b) did not reveal any clearly differentiating pragmatic deficits across aphasic types. Features of the Pragmatic Protocol (Prutting, 1982b) that may account for these differential findings appear to include the following: Firstly, it encompasses a broad range of pragmatic behaviours which are examined in a more global or molar rather than a molecular manner. Secondly, the Pragmatic Protocol (Prutting, 1982b) employs societal criteria of appropriateness. Furthermore the data base used in this study was spontaneous conversation as compared with Penn's study (1983), where topic content was controlled.

\section{Pragmatic Protocol Profiles and Overall Communicative Adequacy Ratings}

The contemporary revival of the awareness of the importance of subjectivity in science (Gould, 1981), resulted in Holland's :Scale of Overall Communicative Adequacy being used in the present study in an effort to provide a global subjective rating of the aphasic individual's communicative adequacy with their partner. Since all communicative partners used in this study were familiar and affiliative, the latter being an acknowledged factor contributing to communicative efficiency (Linebaugh, Kryzer, Oden and Myers 1982), it was apparent that overall, the manner and ease with which these partners communicated with the aphasic, and helped share the communicative burden, facilitated greater commúnicative success with less frustration in the dyad. More effective partners tended to use strategies such as slowing down, stress, cueing, and encouraging the aphasic's use of strategies (e.g. writing, repetition, and a variety of cues such as requesting help from the listener). This use of a range of compensatory strategies by the aphasic was likewise seen to be related to their overall superior performance on the Pragmatic Protocol (Prutting, 1982b). 
The clinical implications of these data are apparently far reaching, yielding support for Linebaugh, et al's suggestion (1982) that it would be valuable to help aphasics (within their limitations) and their partners maximise their share of the communicative burden, and increase the effective use of demonstrated compensatory strategies, thereby enhancing the efficiency of the communication in the dyad.

\section{Social and Clinical Profiles}

While the fluent and non-fluent groups demonstrated significantly different pragmatic competencies, these inter group differences were not observed when comparing performance on the clinical profiles (namely the WAB (Kertesz, 1980) and the CADL (Holland, 1980)). Possible reasons accounting for the stable pattern of discrepant performance apparent across these pragmatic and linguistic tasks include differential task requirements and criteria used in the evaluation of each aphasic's performance. These data imply firstly that in the sample investigated, overall high pragmatic competence was apparently independent of linguistic severity, and secondly that these tools are therefore measuring different aspects of an individual's communicative competence. It is therefore apparent that severity can no longer be measured by linguistic competence alone, but that measures of pragmatic competence need to be considered in relation to these other aspects of language function. This latter interpretation was supported by the overall insignificant correlation between the Pragmatic Protocol (Prutting, 1982b) and the WAB (Kertesz, 1980 ), and the Pragmatic Protocol (Prutting, 1982b) and the CADL (Holland, 1980) in fluent and non-fluent groups separately and combined.

While level of linguistic severity was insignificant in the present study, closer examination of the data reveals some apparent contribution to communicative competence by severity. For example, examination of the data showing fluent and non-fluent group performance on the four subtests of the WAB (Kertesz, 1980) indicates overall superior linguistic performance for the fluent group as compared with the non-fluent group. Since these aphasics are generally the least impaired (Holland, 1980), the data again points toward a role played by linguistic severity in overall communicative competence. Future research is needed to clarify these issues.

\section{Theoretical Implications}

The findings of this study clearly demonstrated the aphasic individuals' retained pragmatic abilities necessary for social competence. Support was thereby rendered for Holland's observation that "aphasics probably communicáte better than they talk" (1977, p. 173). All aphasics' social competence scores were above the level predicted by their linguistic impairments. These data therefore indicate that despite linguistic limitations, relatively intact pragmatic abilities permit effective communication and management with others within the reality of the client's limitations. Despite this, interpretation of pragmatic deficits independent of linguistic structure was problematic. As with the language disordered child (Prutting, et al, 1984), it is evident that some 'spill over' exists between these different areas of communicative competence, and that the processes underlying appropriate use of pragmatic skills are not easily explained apart from the aphasic individual's linguistic limitations. However, overall superior pragmatic competence in relation to other linguistic skills may well account for the differential progress made by aphasic clients of apparently equal severity.

While critical evaluation of traditional theories and methodologies through the telescope of time is crucial to sharpen our focus and reduce distortion, it is equally important to incorporate, rather than exclude the wisdom of our predecessors. It would thus appear valu- able to vicw language within the context of socialisation (Prutting, 1982a) where pragmatics, which is "a pervasive aspect of language which affects the entire communication system" (Prutting and Kirchner, 1983, p.60) is the core.

\section{Chinical Implications}

Since the measures used in the present study served to highlight different communicative competencies and deficits, clearly one needs to consider the range of pragmatic aspects of language in relation to other aspects of language (Foldi et al, 1983; Penn, 1983; Prutting and Kirchner, 1983; Prutting et al., 1984; Prutting, 1984; Wilcox, 1983). More all-encompassing, and dynamic intervention goals could thereby emerge, aimed to enhance structural and functional aspects of communication in relationship to one another.

The value of a societal measure such as the Pragmatic Protocol (Prutting, 1982b) as a means of approaching the assessment of social competence and a context for interpreting a variety of communicative measures likewise yiclds several clinical implications.

Since competence lies in the relational system, the dyad is necessarily the unit of analysis, whose behaviours are judged in terms of societal criteria of appropriateness rather than clinical criteria of correctness. Since these criteria take cognisance of the societal values surrounding the client, facilitating a 'real world prognosis' (Marshall, 1982 cited by Penn, 1983), our criteria for dismissal from remediation will need to shift so that dismissal occurs when the client can manage his/her relationships in a personally appropriate and effective manner within the limitations imposed by his/her stroke. Furthermore, intervention goals can emerge directly from the areas assessed by the Pragmatic Protocol (Prutting, 1982b) in which targets are always embedded within this framework (Prutting, 1984). Such a framework presupposes interactional, contextually based exchanges related to ongoing communicative situations at the level at which the client can meaningfully participate. Since the use of this tool serves to highlight the residual compensatory strengths of each individual, rather than simply faulting them for their inaccuracies and linguistic limitations, emerging intervention goals would be based inherently upon a strength, rather than a deficit model.

These data and emerging issues constitute a changing paradigm. While the results of the present study have provided some preliminary answers, they have raised many more questions. The 1980's will undoubtedly continue to add further in-depth understanding of aphasic pragmatic abilities in relation to other aspects of their communicative competence. In attempting to merge these changing views of theory with practice, aphasiologists need to heed Prutting and Kirchiners' apt comment that "new advances always require a respect for time in order to fit them into our existing schemas" (1983, p.48).

\section{ACKNOWLEDGEMENTS}

The writer expresses her sincere gratitude to Carol Prutting, Department of Speech and Hearing Sciences, University of California, Santa Barbara, for her invaluable guidance as the supervisor of the Masters' dissertation on which this paper is based.

\section{REFERENCES}

Davis, G., \& Wilcox, M.J. Incorporating parameters of natural conversation in aphasia treatment. In R. Chapey (ed.), Language intervention strategies in adult aphasia. Baltimore, Williams \& Wilkins, 1981. 
Foldi, N. S Cicone, M. \& Gardner, H. Pragmatic aspects of communication in brain-damaged patients. In S.J. Segalowitz (Ed.), anguage functions and brain organisation. New York, Academic Press, 1983.

Gould, S. The mismeasure of man. New York, W.W. Norton and Company, 1981 .

Guilford, A.M., \& O'Connor, J.K. Pragmatic functions in aphasia. J. Commun. Disord., 15, 337-346, 1982.

Holland, A.L. Some practical considerations in aphasia rehabilitation. In M. Sullivan and M.S. Kommers (Eds.), Rationale for adult aphasia therapy. Nebraska, University of Nebraska Medical Center, 1977

Holland, A.L. Communicative abilities in daily living. Baltimore, University Park Press, 1980.

Holland, A.L. Observing functional communication of aphasic adults. J. Speech Hear. Disord., 47, 50-56, 1982.

Holland, A.L. Spontaneous recovery from stroke: An investigation of its earliest phases. Paper presented at the Academy of Aphasia, Minneapolis, Minnesota, 1983.

Kazdin, A.E. Assessing the clinical or applied importance of behaviour change through social validation. Behaviour Modification, 1, 427-452, $197 \hat{7}$

Kertesz, A. Western Aphasia Battery. London, Ontario Canada, University of Western Ontario, 1980.

Linebaugh, C.W., Kryzer, K.M., Oden, S.E. \& Myers, P.S. Reapportionment of communicative burden in aphasia: A study of narrative interactions. In R.H. Brookshire (Ed.), Clinical aphasiology conference proceedings. Minneapolis, MN, BRK Publishers, 1982.

Mueller, S.L. An investigation in social competence using clinical and societal profiles: MA thesis, University of California, Santa Barbara, 1983.

Penn, M.C. Syntactic and pragmatic aspects of aphasic language. Doctoral dissertation, University of the Witwatersrand, Johannesburg, South Africa, 1983.

Prutting, C.A. Pragmatics as social competence. J. Speech Hear. Disord. , 47, 123-134, 1982a.

Prutting, C.A. Observational protocol for pragmatic behaviours. Developed for the University of California, Santa Barbara Speech and Hearing Clinic, Clinic Manual, 1982b.

Prutting, C.A., \& Kirchner, D. Applied pragmatics. In T. Gallagher and C. Prutting (Eds.), Pragmatic assessment and intervention issues in language. San Diego, College-Hill Press, 1983.

Prutting, C.A., Kirchner, D., Hassan, P., \& Buen, P. A societal appraisal of pragmatic behaviours. Unpublished manuscript, University of California, Santa Barbara, 1984.

Wertz, R.T., Weiss, D., Kurtzke, J.F., et al., A comparison of clinic, home and deferred treatment of aphasia. Veterans $\mathrm{Ad}$ ministration Cooperative Study Protocol, V.A. Hospital, Martinez, California, 1978.

Wertz, R.T. Personal communication, V.A. Hospital, Martinez, California, 1984.

Wilcox, M.J. Aphasia: Pragmatic considerations. Topics in Language Disorders, 3, 35-48, 1983

\title{
The Profile of Communicative Appropriateness: A Clinical Tool for the Assessment of Pragmatics
}

\author{
Claire Penn Ph.D (Witwatersrand) \\ Department of Speech Pathology \& Audiology, \\ University of the Witwatersrand, Johannesburg
}

\begin{abstract}

\section{OPSOMMING}

The clinical profile is a method of characterising language which has become increasingly popular in recent years. Essentially "... a linguistic profile is a principled description of ... those features of a person's ... use of language which will enable him to be identified for a specific purpose." (Crystal, 1982). The format of such a profile is the presentation of a wide range of variables simultaneously so that the clinician is able to see at a glance the communicative assets and deficits of a patient.
\end{abstract}

The Profile of Communicative Appropriateness - a newly developed profile for the characterisation of pragmatics is described. The theoretical background to this profile is covered as well as its main components. Its application to a group of eighteen aphasic patients is outlined, results suggesting that patient groupings on the profile could be predicted in terms of severity but not in terms of type of aphasia. Explanations for this finding are discussed and the potential utility of this profile is suggested.

Die Profile of Communicative Appropriateness - 'n nuttontwikkelde profiel vir die karakterisering van pragmatiek word beskryf. Die teoretiese rasionaal hieragter en die hoofkomponente van die profiel word behandel. Die toepassing hiervan op 'n groep van agtien afatiese pasiente word omskryf. Resultate dui daarop dat die pasientgroeperings aanduidend kan wees van die erns van afasie maar nie van die tipe afasie nie. Verduidelikings hiervoor en die potensiële bruikbaarheid van die profiel word bespreek.

The main purpose of such a profile according to Crystal (1982) is to provide not only a comprehensive description of a patient's data but also an adequate basis for remedial intervention. It is not a standardized measure; nor is it an exhaustive linguistic description. The profile is, however, a compromise to the clinician faced with the realisation that language disability requires comprehensive and individual description. The amount of information contained on a profile is determined by the behaviours being measured 